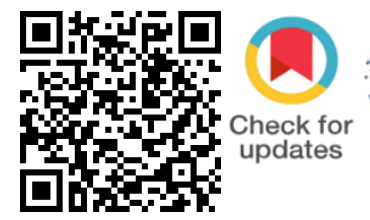

\title{
Medicinal Plant Resources of Shivamogga, Karnataka
}

\author{
Arunakumar N C ${ }^{1} \mid$ Veeranna B Shettar ${ }^{2} \mid$ Ranjith $\mathrm{Y}^{3}$
}

${ }^{1}$ Department of Chemistry, Sahyadri Science College, Kuvempu University, Shivamogga - 577203

2,3 Department of Botany, Sahyadri Science College, Kuvempu University, Shivamogga - 577203

To Cite this Article

Arunakumar N C, Veeranna B Shettar and Ranjith Y, “ Medicinal Plant Resources of Shivamogga, Karnataka”, International Journal for Modern Trends in Science and Technology, Vol. 07, Issue 01, January 2021, pp.- 96-98.

\section{Article Info}

Received on 28-November-2020, Revised on 21-December-2020, Accepted on 02-January-2021, Published on 11-January-2021.

\section{ABSTRACT}

The present study deals with the documentation of aromatic plant resources in Shivamogga district of Karnataka. The peoples of this area have a very good knowledge about the usage of these plants. Elder peoples of this area have common knowledge and easy cure for many common ailments and prepare different types of medicines from different plant parts. India is rich in medicinal and aromatic plants and play an important role in the country's agricultural sector due to quantitative and qualitative advantages. These plants can help small-scale farmers to strengthen their livelihoods and capacity to build successful and sustainable activities. A total of 40 aromatic plant species belonging to 33 genera and distributed over 22 families were recorded in the present study area.

KEYWORDS: Medicinal value, Shivamogga district, Traditional Knowledge.

\section{INTRODUCTION}

The knowledge of medicinal plants has been accumulated in the course of many centuries based on different medicinal systems such as Ayurveda, Unani and Siddha. In India it is reported that traditional healers use 2500 plant species and 100 species of plants serve as regular sources of medicine (Pei, 2001). In recent years, there has been a tremendous range of interest in the medicinal plants especially those used in traditional systems of medicines. Drugs obtained from plant are believed to be much safer andexhibit a remarkable efficacy in the treatment of various ailments (Siddiqui, et.al. 1995). the folk medicinal traditions play a reflecting and prominent role in human and environment interaction (Chopra and Nayar, 1956). It is estimated that 70 to
$80 \%$ of the peopleworldwide rely chiefly on traditional health care system and largely on herbal medicines (Farnsworth et.al. 1985, 1991, Shengii 2002, Shanley and Luz, 2003; Hiremath et al.,2010).

About 1000 years ago healers in the Aztec and Maya Indian cultures of Mexico and Central America were experimenting with natural curing substances and exploited at least 132 medicinal herbs for the treatment of specific ailments (Evans, 2004; Berdan, 2005; Ashish Kumar and Jnanesha , 2016).

Essential oils are isolated from Aromatic plant materials by various distillation process. Whereas, other volatile isolates are obtained by solvent extraction. Aromatic plants contain odorous, 
volatile, hydrophobic and highly concentrated compounds called essential oils. These are obtained from several organs of the plant such as flowers, buds, seeds, leaves, twigs, bark, wood, fruits and roots (Brenes \& Roura, 2010; Ashish Kumar and Jnanesha, 2016). The essential oils are complicated mixtures of secondary metabolites consisting of low-boiling-point phenylpropenes and terpenes (Greathead, 2003 ; Ashish Kumar and Jnanesha , 2016). Essential oils are used for consumer goods viz., detergents, soaps, toilet products, cosmetics, pharmaceuticals, perfumes, confectionery food products, soft drinks, beverages and insecticides.

\section{MATeRials AND MethodS}

The present study is an attempt to know the diversity of aromatic plants in Shivamogga district (Figure 1) of Karnataka. Periodic field survey was carried out during July 2017 to December 2017. Standardmethods were followed for the collection of plant materials and preservation of plant species. Voucher specimens were collected identified, by referring standard flora (Hooker, 1884; Gamble, 1936; and Saldhana, 1984).

\section{RESULTS AND DISCUSSION}

In this study, a total of 40 aromatic plant species belongings to 33 genera comprising of 22 families were recorded in Shivamogga District, Karnataka. Checklist of aromatic plants is shown in Table 1. They had been cross checked by literature previously reported for usage. Figure 2 depicts the percentage occurrence of these plants in each family.

The traditional knowledge about utilization of local plant species is vital in alternate healthcare system as well as for the self sustenance of local population. High costs coupled with numerous side effects of synthetic drugs are forcing people to depend on the locally available herbal medicine for their healthcare needs. Methods of medical treatment used by knowledgeable elder people and local herbal healers in Shivamogga taluk were totally traditional, very effective and acquired through their ancestors orally. It is high time that these herbal species are scientifically evaluated and conserved for the well being of mankind. These traditional herbal formulations need further pharmacological investigations to prove their efficacy and also develop new drugs for the effective treatment of chronic diseases (Shivanna \& Rajakumar,2010).
Green plants synthesis and preserve a variety of biochemical products, many of which are extractable and used as chemical feed stocks or as raw material for various scientific investigations. Many secondary metabolites of plant are commercially important and find use in a number of pharmaceutical compounds. However, a sustained supply of the source material often becomes difficult due to the factors likeenvironmental changes, cultural practices, diverse geographical distribution, labour cost, selection of the superior plant stock and over exploitation by pharmaceutical industry (Ashish Kumar and Jnanesha, 2016).

Table-1: List of plants of Medicinal aromatic plants in Shivamogga district

\begin{tabular}{|c|c|c|}
\hline $\begin{array}{l}\text { Sl. } \\
\text { No }\end{array}$ & Scientific name & Family \\
\hline 1. & Abutilon indicum & Malvaceae \\
\hline 2. & Achyranthus aspera & Amaranthaceae \\
\hline 3. & Aegle marmelos & Rutaceae \\
\hline 4. & Bacopa monnieri & Plantaginaceae \\
\hline 5. & Cymbopogon citratus & Poaceae \\
\hline 6. & Citrus limonum & Rutaceae \\
\hline 7. & Centella asiatica & Apiaceae \\
\hline 8. & Coriandrum sativum & Apiaceae \\
\hline 9. & Capsicum annuum & Solanaceae \\
\hline 10. & Cinnamomum camphora & Lauraceae \\
\hline 11. & Cinnamomum cassia & Lauraceae \\
\hline 12. & Cinnamomum zeylanicum & Lauraceae \\
\hline 13. & Cassia fistula & Caesalpinaceae \\
\hline 14. & Citrus aurantifolia & Rutaceae \\
\hline 15. & Curcuma longa & Zingiberaceae \\
\hline 16. & Eucalyptus globulus & Myrtaceae \\
\hline 17. & Elettaria cardamomum & Zingiberaceae \\
\hline 18. & Eclipta alba & Asteraceae \\
\hline 19. & Ficus racemosa & Moraceae \\
\hline 20. & Ficus religiosa & Moraceae \\
\hline 21. & Jasminum multiflorum & Oleaceae \\
\hline 22. & Lawsonia inermis & Lythraceae \\
\hline 23. & Mentha piperita & Lamiaceae \\
\hline 24. & Ocimum bassilicum & Lamiaceae \\
\hline 25. & Ocimum sanctum & Lamiaceae \\
\hline 26. & Piper longum & Piperaceae \\
\hline 27. & Piper nigrum & Piperaceae \\
\hline 28. & Solanum nigrum & Solanaceae \\
\hline 29. & Solanum indicum & Solanaceae \\
\hline 30. & Syzygium aromaticum & Myrtaceae \\
\hline 31. & Santalum album & Santalaceae \\
\hline 32. & Tinospora cordifolia & Menispermaceae \\
\hline 33. & Tagetes erecta & Asteraceae \\
\hline 34. & Tamarindus indica & Caesalpiniaceae \\
\hline 35. & Trigonella foenum & Fabaceae \\
\hline 36. & Vitex negundo & Lamiaceae \\
\hline 37. & Vanilla sp. & Orchidaceae \\
\hline 38. & Withania somnifera & Solanaceae \\
\hline 39. & Zingiber officinale & Zingiberaceae \\
\hline 40. & Ziziphus jujuba & Rhamnaceae \\
\hline
\end{tabular}




\section{ConClusion}

In this study, we have documented the list of aromatic medicinal plants in the Shivamogga district of Karnataka. This study can serve as baseline information on the medicinal plants prosperity of this area. Further study will throw more light about the vast wealth of ethnobotanical information. Further pharmacological and clinical studies on these plants will provide effective natural medicines for various treatment and it will also be useful to determine in the bio-prospecting potential of these plants. The conservation status of aromatic plant species in trade should also be studied. This clearly opens up a huge challenge for conservationist, policy makers, researchers, industry and farmers to manage one of the most important natural resources, medicinal and aromatic plants judiciously.

\section{REFERENCES}

[1] Hiremath,V.T.,M.M.J. Vijaykumar and T.C. Taranath. Survey on Ethno- medicinal Plants of Jogimatti Forest Chitradurga District, Karnataka, India. Environ. We Int. J. Sci. Tech. 5 :223- 233.2010.

[2] Hooker Flora of British India, Vol.1-7. Dehra Dun: Bishan Singh Mahendrapal Singh.1978.

[3] Pei..Ethnobotanical approaches of traditional medicine studies some experiences from Asia, Pharma Bio 39, 74-79.2001.

[4] Saldanha, Flora of Karnataka. New Delhi: Oxford and IBH Publishing Co.1984.

[5] Shanley, and Luz. The impacts of forest degradation on medicinal plant use and implication for health care in Eastern Amazonia. Bio Science, 53 (6), 573 - 584.2003.

[6] Shivanna, M.B \& N Rajakumar. Ethno- medico-botanical knowledge of rural folk in Bhadravathi taluk of Shimoga district, Karnataka. Indian Journal of Traditional Knowledge Vol. 9 (1), January 2010, pp. 158-162.2010.

[7] Siddiqui, M.A.A., John, A.Q., Paul, T.M. Status of some important medicinal and aromatic plants of Kashmir Himalaya. Advances in Plant Sciences, 8, 134-139.1995.

[8] Chopra, LC, and Nayar, MC. Glossary of Indian Medicinal Plants. Council of Scientific and Industrial Research, New Delhi. 1956.

[9] Evans, S. T. Ancient Mexico and Central America. New York: Thames and Hudson.2004.

[10] Farnsworth, and Soejarto, Global importance of medicinal plants. In: Akerele, O.; Heywood, V. and Synge, H., (Eds.), Conservation of Medicinal Plants. Cambridge (United Kingdom): Cambridge University Press. pp. 25 - 51. 1991.

[11] Farnsworth,N.R; Akerele, O. and Bingel. A.S. Medicinal plants in therapy. Bulletin of the World Health Organization, 63, $965-981.1985$.

[12] Gamble Flora of Presidency of Madras, vol.1-3. Dehra Dun: Bishan Singh Mahendrapal Singh.1994. 